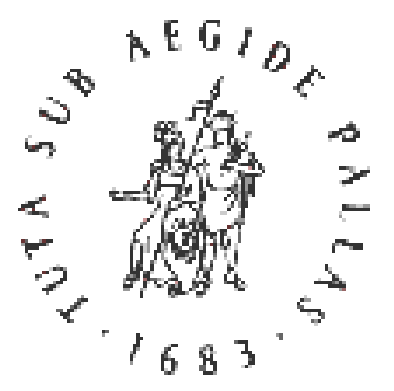

B R I L L

\author{
Appearances and Impressions \\ Author(s): Rachel Barney \\ Source: Phronesis, Vol. 37, No. 3 (1992), pp. 283-313 \\ Published by: BRILL \\ Stable URL: http://www.jstor.org/stable/4182417 \\ Accessed: 18/09/2010 11:46
}

Your use of the JSTOR archive indicates your acceptance of JSTOR's Terms and Conditions of Use, available at http://www.jstor.org/page/info/about/policies/terms.jsp. JSTOR's Terms and Conditions of Use provides, in part, that unless you have obtained prior permission, you may not download an entire issue of a journal or multiple copies of articles, and you may use content in the JSTOR archive only for your personal, non-commercial use.

Please contact the publisher regarding any further use of this work. Publisher contact information may be obtained at http://www.jstor.org/action/showPublisher?publisherCode=bap.

Each copy of any part of a JSTOR transmission must contain the same copyright notice that appears on the screen or printed page of such transmission.

JSTOR is a not-for-profit service that helps scholars, researchers, and students discover, use, and build upon a wide range of content in a trusted digital archive. We use information technology and tools to increase productivity and facilitate new forms of scholarship. For more information about JSTOR, please contact support@jstor.org.

BRILL is collaborating with JSTOR to digitize, preserve and extend access to Phronesis. 


\title{
Appearances and Impressions
}

\author{
RACHEL BARNEY
}

According to Sextus Empiricus, the Pyrrhonian sceptic adheres to the appearances (ta phainomena, $\mathrm{PH} 1.21$ ). Without insisting that things are entirely as he says, he is willing to say how they presently appear to $\mathrm{hm}(\mathrm{PH}$ 1.4). His uses of the word 'is' mean 'appears' $(P H 1.135)$; even his philosophical slogans should be understood as referring to appearance $(P H 1.15$, $1.191,1.198-9,1.200)$. Appearances are the sceptic's practical criterion and guide to action ( $P H$ 1.21-4).

The purpose of this paper is to offer an interpretation of the sceptic's commitment to appearances, drawing both on the commonplace notion of appearance and on some of its philosophical uses prior to Sextus. Sextus never fully explains what he means by 'appearance'; and while we need to understand his meanings to interpret the sceptical stance, that stance sets restrictions on the form that a sceptical 'concept of appearance' might take. Sextus takes the view that it is inappropriate for the sceptic to argue about the meanings of words, and repeatedly states a preference for using them in a loose way $(P H 1.191,1.195,1.207)$. Behind this view lies the general sceptical programme of opposition to dogmatic attempts to state the real nature of any phenomenon. Sextus' refusal to offer a sceptical account of appearance is not incidental, and it would be wrong to assume the existence of an implicit account awaiting our discovery.

At the same time, Sextus' concern to prevent misunderstanding of scepticism makes him careful to note ambiguities and special senses in the sceptical vocabulary (e.g., $P H .1 .13,1.21,1.187 \mathrm{ff}$.). So his reticence about the vocabulary of appearance, in conjunction with his opposition to dogmatism, suggests that Sextus means to use these terms in a straighforward, commonplace way. Moreover, the other side of the sceptic's critique of dogmatism is his positive commitment to bios - 'real life', the everyday world of pre-philosophical practice and experience (e.g., $P H$ 1.23-4, 2.102, 3.235). And the espousal of bios is bound up with the commitment to appearances: "So adhering to the appearances we live undogmatically 
according to everyday observation (biôtikê têrêsis)" (PH 1.23). This commitment to the everyday reinforces the prospect that the sceptic's understanding of appearances will prove to be a commonplace one. On the other hand, the sceptic's espousal of bios is problematic; indeed, it forms part of his defense against hostile characterisations as a radical who subverts all that makes bios possible. While the sceptic may speak in favour of the everyday, he is not its representative; so if Sextus does use an ordinary sense of 'appearance', we should expect that some aspect of this use will be extraordinary.

We may nonetheless take the everyday conception of appearances as at least a starting-point for the investigation of sceptical appearances. But the content of this conception is itself quite unclear. It is notorious that ordinary appearance-language may be used to say very different kinds of things: in particular, that it may relate variously to the beliefs or judgements of the speaker. Often appearance-language appears to be used to express a tentative judgement about some state of affairs - as in this sentence. But such uses can be contrasted with others which seem to express private states or experiences. We may accordingly be inclined to distinguish different senses of appearance-terms; and such distinctions have naturally been invoked in recent interpretations of Sextus Empiricus. Consider the claim of Annas and Barnes:

"The Pyrrhonist, when he talks about appearances, is saying nothing at all about his beliefs, tentative or firm: he intends to register how things strike him, not how much confidence he is putting in the way they strike him. Philosophers have spoken of a 'phenomenological' and a 'judgemental' use of the word 'appear': in the phenomenological sense, the verb expresses the way things impress us, while in the judgemental sense, it expresses our beliefs. Throughout the Ten Modes the word 'appear' must be taken in its phenomenological sense."

The attraction of this 'phenomenological' reading is that it promises to uphold the radicalism of the sceptic's opposition to dogmatism. If sceptical

1 Julia Annas and Jonathan Barnes, The Modes of Scepticism (Cambridge, 1985), pp. 23-4. Non-judgemental interpretations of the sceptic are also presented by Jonathan Barnes, "The Beliefs of a Pyrrhonist", Elenchos 4 (1983), pp. 5-43; by M.F. Burnyeat, in three papers: "Can the Sceptic Live His Scepticism?", in Doubt and Dogmatism, eds. Malcolm Schofield, Myles F. Burnyeat, and Jonathan Barnes (Oxford, 1980), pp. 20-53,

$\rightarrow$ "Idealism and Greek Philosophy: What Descartes Saw and Berkeley Missed", Phil. Rev. 91 (1982), pp. 3-40, and "The Sceptic in His Place and Time", in Philosophy in History, eds. Richard Rorty, J.B. Schneewind, and Quentin Skinner (Cambridge, 1984), pp. 22554; and, in effect, by Charlotte Stough, "Sextus Empiricus on Non-Assertion", Phronesis 29 (1984), pp. 137-164: see esp. p. 139, but not pp. 141-2 n.7. 
appearance-statements are 'judgemental' assertions - however qualified or restricted in scope - then the difference between dogmatist and sceptic seems to be diminished to one of tone or degree. If on the other hand the sceptic's utterances bypass any degree of doxastic commitment, they differ from the dogmatist's pronouncements in kind.

However, there are substantial difficulties with any wholly non-judgemental interpretation of the sceptic. One is that it is far from obvious what if anything - 'phenomenological' appearance-language can mean. The metaphors of 'striking' and 'impressing' are stipulated by Annas and Barnes to refer not to the passing of a judgement or the formation of a belief, even a particularly immediate and unreflective one, but to something essentially different. But it is difficult to get a clear notion of what this something might be; it becomes particularly problematic when we consider that the sceptic's appearances constitute the whole range of his discourse, with no limitation as to subject-matter. Whatever scope there may be for 'phenomenological' expressions of 'impressions' in everyday life seems unlikely to extend, as the sceptic's must, to views on the strength of various arguments about physics. In these contexts it is hard to see what the metaphors of striking and impressing can accomplish - beyond adding a coloration of passivity and immediacy to what are judgements nonetheless. M.F. Burnyeat also offers a 'non-epistemic' account of the sceptic (i.e., a non-judgemental one: knowledge is clearly beside the point); and he points out, as a problem for the sceptic so understood, that it seems wrong to distinguish the appearance or impression from the passing of a judgement in cases of abstract argument. "In the philosophical case, the impression, when all is said and done, simply is my assent to the conclusion of an argument, assent to it as true."

My own impression is that there is, in bios, no 'phenomenological' or otherwise non-judgemental sense of appearance. My aim in this paper will be to show that we need not attribute such a sense to the Pyrrhonian sceptic. To see why, it will help us first to consider the ancient discussions of appearances and impressions which must have informed the sceptic's use of them (sections I-IV). I will then sketch a wholly judgemental interpretation of the sceptic's appearances, one which takes account both of this history and of the sceptic's rejection of dogmatism (sections V-VII). ${ }^{3}$

\footnotetext{
2 Burnyeat 1980 (op.cit. n.1), p. 53.

${ }^{3}$ As a judgemental interpretation of the sceptic, this paper is greatly indebted to the work of Michael Frede, in particular to "The Skeptic's Beliefs", in Frede's Essays in Ancient Philosophy (Minneapolis, 1987), pp. 179-200 (first published 1979); to "The Sceptic's Two Kinds of Assent and the Question of the Possibility of Knowledge", in Philosophy in History (op.cit., n.1), pp. 255-278; and to a seminar given at Princeton
} 
In Republic X, Plato discusses some standard cases of deceptive appearances in order to establish that mimetic art has its power over an inferior constituent of the soul $(602 \mathrm{c}-3 \mathrm{~b}) .{ }^{4} \mathrm{He}$ points out that, due to 'the vagaries of sight', the same magnitude appears (phainetai) different sizes from near and far, the same objects appear bent and straight, and so on. Measuring and counting and weighing can help us in this regard, so that what appears (to phainomenon) greater or less or more or heavier does not 'rule' in us, but rather what these procedures of investigation have determined to be the case. The use of these procedures belongs to the 'calculative' part of the soul. But when this reports its findings, it often happens that 'the opposites appear' at the same time. ${ }^{5}$ Now by application of the general principle of

University in 1990. However, I describe the content of the sceptic's judgements in different and probably incompatible terms. I would also like to thank Michael Frede, Charles Brittain, Fiona Cowie, John Keaney and especially Stephen Menn for helpful discussions of various aspects of this paper.

"Phantasia in Plato is discussed by Allan Silverman, "Plato on Phantasia", Classical Antiquity 10 (1991), pp. 123-147; in both Plato and Aristotle $\rightarrow$ Kimon Lycos, "Aristotle and Plato on 'Appearing' ", Mind n.s. 73 (1964), pp. 496-514, and by D.A. Rees, "Aristotle's Treatment of Phantasia", in Essays in Ancient Greek Philosophy, ed. John Anton with George Kustas (Albany, 1971), pp. 491-504. Aristotle's account is related in greater detail by Martha C. Nussbaum, "The Role of Phantasia in Aristotle's Explanation of Action", Essay 5 in Nussbaum's Aristotle's De Motu Animalium, (Princeton, 1978), pp. 221-269; Malcolm Schofield, "Aristotle on the Imagination", in Aristotle on Mind and the Senses, eds. G.E.R. Lloyd and G.E.L. Owen (Cambridge, 1978), pp. 99$1 \rightarrow$ Gerard Watson, "Phantasia in Aristotle, De Anima 3.3", CQ 32 (1982), pp. 100-13; and Michael Wedin, Mind and Imagination in Aristotle (New Haven, 1988).

${ }^{5}$ Toutôi de pollakis metrêsanti kai sêmainonti meizô atta einai ê elattô hetera heterôn ê isa tanantia phainetai hama peri tauta (= ta auta) $(602 \mathrm{e} 4-6)$. The correct translation of this sentence has been the subject of some debate. Jowett and Campbell rightly note that contradictory beliefs should not be attributed to the logistikon (contra Stallbaum, and more recently Murphy); to avoid doing so, they detach the datives from phainetai, taking them as in effect equivalent to a genitive absolute (Benjamin Jowett and Lewis Campbell (eds., notes, essays), Plato's Republic 3 vols. (Oxford, 1894), vol. 3, pp. 451-2; G. Stallbaum (ed., commentary), Platonis Opera Omnia vol. 3. sect. 2 (2nd. edn., Gotha, 1859), pp. 389-90; N.R. Murphy, The Interpretation of Plato's Republic, (Oxford, 1951), pp. 239-43.) Adam, rightly finding this construction suspect, holds that tanantia are the opposites of to phainomenon meizon ê elatton etc.in $602 \mathrm{~d} 8$, and that they phainetai to the logistikon when it has performed its calculation (James Adam (ed., notes, commentary), The Republic of Plato 2 vols. (2nd edn., Cambridge, 1963), vol. 2, pp. 407-8 note ad loc., pp. 466-7). But this reading must reach back rather far to get a (singular) correlate for tanantia, and it involves attributing the experience of appearance to the logistikon, which seems wrong given the previous association of the apparent with the delusory (596e4, 
non-contrariety enunciated earlier (Republic 436a-c), it is impossible for the same thing at the same time to form opposite judgements (enantia doxazein) about the same thing. So, Plato concludes, what judges (to doxazon) contrary to the results of measurement can't be identical with the element which trusts in calculations; it must therefore be an inferior part of the soul. The argument is intended to provide an explanatory model for all kinds of errors of judgement about matters of value, such as overindulgence in emotion (605b-c; cf. Protagoras 356b-7b, Philebus 4le-2c).

So a stick submerged in water appears bent to me when some lower element in my soul so judges or opines; 'the apparent' is in general what I, or rather some constituent of me, initially and unreflectively takes to be the case on the basis of perception. In the Sophist Plato expands on this account by associating what appears with judgement (doxa), thought (dianoia) and phantasia (Sophist 263-4b). Thought is the inward, soundless dialogue carried on by the mind with itself; judgement is the internal version of assertion and denial. And when judgement occurs, not independently, but through perception, then 'an experience of this sort' (to toiouton pathos) is correctly called 'appearance' (phantasia) (264a4-6). So what we mean by 'it appears' (phainetai) is a 'commingling' (summeixis) of perception and judgement (264b1-2). Phantasia is thus introduced by Plato simply as the substantive correlative with phainesthai, used in a judgemental sense. ${ }^{6}$

598a5-b5, 602b2, c8, d8). Halliwell holds that, although the opposites appear to the logistikon, it need not actually believe them; but then it is unclear why Plato should assume immediately afterwards that two contradictory opinions are in play (S. Halliwell (trans., commentary), Plato: Republic 10 (Aris and Phillips, 1988), p. 134). I suggest reading the datives as governed not by phainetai but by tanantia (which is indeed closer to them). Roughly: "Often the opposites of this - when it has measured and indicates that some things are greater or less than or equal to others - appear at the same time, about the same things." As 602e8-3a2 explains, phainetai is here equivalent to doxazesthai. What experiences the opposite appearances, i.e. judges contrarily, is, as one would expect from the connotations of phainetai, the inferior part of the soul. What its judgements are contrary $t o$ is the logistikon, or more accurately the findings which the logistikon communicates (semainonti). Hence the inferior part is to toutoi enantioumenon (6)3a7). There is no problem with using the logistikon to stand in for what it asserts in the enantia + dative construction: cf. Republic 453c3-4, Euthyphro 6a4-5, Protagoras 339b9-10 and Laws 810d3-4.

"Phantasia has the same sense at Theaetetus 152c1. In the Philebus, where a doxa is again an unspoken judgement, an internal 'scribe' records perceptual judgements in our soul, followed by an internal 'painter' of 'images': eikones (39b6-7) or, of the future, phantasmata (40a9). This suggests, though the passage is difficult, that such an image is derivative both of perception and of a distinct propositional judgement. So if this image is to be identified with the phantasia of the Sophist, there seems to have been some revision to Plato's account; but the result is no less judgemental. 
On the judgemental account of appearances, in saying how things appear to us we render our judgement: we say how we think things are. To say that the stick appears bent to me is to say that my phantasia of the stick is that it is bent; and this is to say that I silently affirm the thought (which somehow involves perception) that it is so. But the 'apparent' is characterically associated with visual perception, and especially with its weaknesses; hence it is contrasted with what is or might be found to be the case on closer examination or reflection. Thus the peculiar function of appearance-language is to mark a judgement as defeasible by being based on preliminary, and in particular perceptual information. We use appearance-language to express the recognition that some authoritative procedure of investigation might well give a result opposed to the judgement we state.

A judgemental account is thus committed to the view that, even in cases of optical illusion, what constitutes an 'appearance' is not some bare sensory stimulus but a judgement that something is the case - or at least an inclination so to judge, which can reasonably be interpreted in psychodynamic terms (as by Plato) as a preliminary judgement passed by some lower cognitive authority. This is a strong claim, but not an utterly implausible one; and the opponent of the judgemental account is forced to the equally strong assertion of a world-related cognitive process accessible to consciousness ('being appeared to') which cannot be represented as issuing judgements, no matter how preliminary or tentative. Which side can make out the better case for itself is a question beyond the scope of this essay; but it should at least be noted that the resilience of appearances which conflict with our preferred and more considered judgements (such as optical illusions) is not decisive evidence against the judgemental view. On a Platonist account, it is no evidence at all: the judgements of the lower part of the soul may be as stubborn as any others. On the other hand, a judgemental account is better able to explain the case of Anaxagoras. According to Cicero, he not only denied that snow is white, but "said that to him, because we knew that water was black and snow was solidified water, it did not even appear (videri) white" (Acad. II.xxxi.100). For snow to appear white to Anaxagoras, "knowing" what he did, would have been for him to experience an optical illusion. The heroic strength of his philosophical convictions preserves him from this experience. But Anaxagoras' knowledge can hardly have changed any wholly pre-judgemental operations of his senses; it has rather succeeded in suppressing in him the normal tendency towards a contrary preliminary judgement. 
In De Anima, Aristotle introduces his own account of phantasma through arguments that it cannot be identified with perception, knowledge, intelligence, judgement (doxa), or, contra Plato, any combination of judgement and perception (De Anima 428a1-29a9). (Supposition (hupolêpsis) has already been excluded at $427 \mathrm{~b} 16-24)$. One thing notable about these arguments is the extent to which they rely on a determinate and un-Platonic conception of what phantasia must be. For example, Aristotle's argument that phantasia cannot be identical with judgement depends on his own distinctive conception of phantasia as a central cognitive function of the lower animals (e.g., Metaph. 980b25-6, De An. 429a4-8, 433b27-30). Judgement involves conviction (pistis), which involves having been persuaded (to pepeisthai), which involves reason (logos). Since lower animals lack conviction and reason, though many have phantasia, the two cannot be identical (428a19-24, cf. 428a9-11). Aristotle's constructive account is already implicit in the opening characterisation of phantasia as that by which an image (phantasia) comes before the mind (428a1-2). It is as the provider of images to the soul that Aristotle's phantasia turns out to be derivative of perception ( $D e A n .428 \mathrm{~b} 11-9 \mathrm{a} 9$ ), and engaged in by what perceives (De Ins. 459a14-22, De Mem. 450a10-14), it is also naturally invoked to account for memory, dreams and visual hallucinations (De Mem. 450a22-25, De Ins. 458b10-9a22). ${ }^{7}$

The conception might seem sufficiently different from Plato's judgemental phantasia that the two should be taken to refer to distinct and perhaps compossible entities. ${ }^{8}$ But Aristotle, like Plato, wants to use phan-

\footnotetext{
7 That Aristotle's phantasmata are first and foremost mental images, and his constructive account of phantasia his explanation of what produces them, seems to me the most plausible reading of De Anima 111.3 and of the use made of phantasia and phantasmata in the Parva Naturalia (see esp. De An. 427b17-24, De Mem. 449b30-50a11 and 450a2751a17). This view is compatible with recognising Aristotle's desire to correlate phantasia with our uses of phainetai/phainomenon; and the wider scope of the latter terms can account for the way in which phantasia sometimes takes on a broader sense (as at $E E$ 1235b27-9, EN 1114a32). I take it that such broadening is what Aristotle sets aside as 'metaphor' at $D e \boldsymbol{A n}$. 428a1-2, in favour of a stricter correlation with mental imagery (contra Nussbaum (op.cit. n.4), pp. 252-5). However, Aristotle's conception of phantasia is unclear and controversial: for more detailed discussions and alternative interpretations see the works cited in note 4.

" This is Cornford's view: he states that at De Anima 428a, "Aristotle means that he is giving phantasia a new sense ('the imaging faculty'), which is not to be confused with Plato's use of the word" at Sophist 264 (Francis M. Cornford (trans., commentary), Plato's Theory of Knowledge, (London, 1935), p. 319 n.2).
} 
tasia to mean that to which we refer in saying how things appear to us ( $D e$ An. 428a6-8, a12-15, De Ins. 460b18-20, EN 1114a31-b3). He accordingly takes our use of appearance-language as providing evidence of the character of phantasia: one argument against the identification of phantasia with perception is that "we don't say when we are exercising (perception) accurately on what is perceived that 'this appears (phainetai) to us to be a person'. But rather it's when we aren't perceiving distinctly . . ." (428a1215). ${ }^{9}$

It is presumably because of this disagreement about the significance of appearance-language that Aristotle goes on to offer a direct argument against the Platonic conception of phantasia (428a24-b9). This argument seems to run as follows. ${ }^{10}$ Aristotle and Plato agree that in saying how something appears we report on our phantasia or phantasma. They further agree that a paradigm case of the apparent is that of an optical illusion, or more broadly a case in which the way something appears to perception differs from how we know it to be. Aristotle claims that in such cases Plato must maintain that the content of the perception and of the judgement are the same, for this will be the content of the phantasia. Now suppose that my established judgement is that the sun is enormous; however, when I look at the sun, it 'appears' to me to be a foot in diameter. What then can my phantasia be, on the Platonic account? If I say, 'The sun appears to me a foot in diameter', expressing my phantasia, then my judgement must have changed to that effect; but this cannot be right, since I have not been dissuaded from or forgotten my previous judgement. Aristotle's rather cryptic remark about an unchanged judgement being both true and false is presumably to the same point (428b7-9). If my phantasia is a combination of judgement and perception then it will be false as regards my present perception of the sun, though true as a judgement about its real size. So when I look at the sun, converting my hupolepsis into phantasia, it is falsified by its new status as a perceptual report, without any change either in its claims about the world or in the fact of the matter.

The example of the size of the sun is also used in De Insomniis, as a simpler basis for the claim that phantasia and judgement are distinct. What governs the soul (to kurion) does not judge "by the same capacity as that by which images (phantasmata) occur. An indication of this is that while the sun appears (phainetai) a foot across, often something else contradicts the

\footnotetext{
"See also Schofield (op.cit. n.4, esp. pp. 118-23) for the dependence of Aristotle's account on linguistic behaviour.

1' Cf. Lycos (op.cit. n.4), pp. 500-3.
} 
phantasia." (460b16-20). Aristotle correlates this with a distinction between what appears (phainetai) and what seems or what one judges to be the case (dokei). Phantasmata are usually, but not always, accepted as doxai: "For on the whole, the ruling part affirms what comes from each sense, if another more authoritative one doesn't oppose it. So while in every case something appears (phainetai), what appears (to phainomenon) doesn't always seem (dokei), unless what judges is held in check or is not moving with its proper motion." (461b3-7, cf. 461b30-2a8). An instance of this would be that pleasure "to some seems (dokei) good, while to others it appears (phainetai) and doesn't seem so (for phantasia and doxa aren't in the same part of the soul)." (EE 1235b27-9) The seeming - the judgemental 'appearance' - requires the acquiescence of the ruling element of the soul: "whenever the soul yields to the phantasia arisen from perception and agrees and assents to what appears, it is called doxa." (Sextus Empiricus describing the Peripatetic view, $A M$ 7.225-6).

Now it may seem that for all his opposition to Plato, Aristotle's view risks collapse into a judgemental one: for Plato would doubtless charge that his phantasmata are really just judgements (doxai) assented to and asserted by the phantasia. We might even think that Aristotle could grant that in Platonic terms this was so; perhaps he would take issue with Plato only on the more general question of whether the activities of parts of soul can legitimately be described in terms appropriate to the whole. However, despite his occasional tendency to speak as though phantasmata were claims made by the phantasia (e.g., De Motu An. 701a32-3), I doubt that Aristotle's view does collapse in this way. For some of the activities of his phantasia clearly involve no tendency at all to think anything true of the world - they are cases of imagining, visualizing, or thinking of rather than thinking that (e.g., De Mem. 449b30ff., De An. 427b17-24). ${ }^{11}$ These non-assertoric uses of mental imagery are perhaps what prompt Aristotle to make the general claim that "phantasia is different from assertion or denial; for truth and falsity involve a combination of thoughts" (De An. 432a10-12). The association of truth and falsity with combination and assertion recalls $D e$ Interpretatione (16a10-20); presumably a phantasma is 'uncombined' in the same way as individual words (and perhaps even strings of nouns and adjectives), which have determinate content but by themselves assert noth-

"These cases do not necessarily represent a problem for Plato's account. He can simply say that he did not mean to include such imaginative processes in his conception of phantasia; and that, since we do not usually use the language of appearance to refer to them, there is no presumption that he should have. 
ing. (Aristotle's claim is perhaps a passing shot against the Sophist account, in which phantasia is a form of assertion and denial (263e 10-4a7)). It seems likely that to make an assertion, a phantasma must be 'combined' with the thought of something in the world, so that it is seen as an image of that something, and as making claims about it. In the case of memory, phantasia draws an analogy with the difference between looking at a picture as a picture and as a portrait of someone (De Mem. 450b20-51a14). Perhaps because he views this seeing-as process as straightforward, Aristotle habitually attributes the truth and falsity of the completed thought of the phantasmata themselves ( $D e A n$. 428a12,18, 428b17). But this is, I suspect, just a cutting of corners: he will not really grant to Plato that a phantasma as such constitutes even the most preliminary or low-level of judgements.

Though the sketchiness of both accounts ensures plenty of scope for further debate, Aristotle's arguments do not seem to me to refute judgemental accounts of appearances in general, or even Plato's in particular. ${ }^{12}$ The general De Anima argument against judgemental accounts depends, first, on Aristotle's own conception of phantasia as a central cognitive function of the lower animals and, second, on the dubious claim that, lacking logos (a word whose ambiguity perhaps plays a role in this view), these animals cannot be said to make judgements. The particular argument against the Platonic 'combination' account is only clearly effective on the assumption that only a single phantasia or perceptual judgement can be in play at any time, so that an occurent perception and an occurrent judgement about the object of perception must share their content. But Plato of all people has no reason to accept this assumption; as Republic $602 \mathrm{c}-3 \mathrm{~b}$ makes explicit, different constituents of the soul can form opposed perceptual judgements concurrently. Nor is any Platonist compelled to accept the

12 Contrast Lycos (op.cit. n.4. pp. 501-8) and Hamlyn (D.W. Hamlyn (trans., introduction, notes), De Anima, Books II and III (Oxford, 1968), pp. 134-4), both of whom hold that Aristotle succeeds in refuting Plato. Also contrast two defences of Plato which seem to me unacceptable. Watson defends Plato at the cost of allowing the aisthesis and doxa components of phantasia to be separable in time and differing in content (op.cit. n.4, p. 112). Silverman holds that "it is open to Plato to claim that the belief involved in the appearance is that the sun appears a foot across, not that the sun is a foot across"; that is. he wants to grant Plato a 'non-epistemic' sense of appearance for such cases (op.cit. n.4. p. 137). This leads to the result that in the Republic case. "The belief involved in the phantasia is that the stick appears bent", so that the "two beliefs" of the individual who has measured are that the stick appears bent and that the stick is straight (p. 138). But these beliefs do not conflict, while those in Plato's passage plainly do (enantia doxazein. 602e8), and must if they are to provide an argument for the division of the soul (602e8-3b4). 
guiding distinction which Aristotle's arguments are intended to support, between phantasia/phainesthai and doxaldokein. It is open to him to insist that any world-related phantasma being consciously 'entertained' as a candidate for assent must have already been affirmed by the judgemental processes of some constituent of the soul, often an inferior one. Such a claim is made more plausible by the existence of non-perceptual 'appearances', which in bios are often clearly judgemental. Indeed a number of Aristotle's uses of phainomena, including at least some of the phainomena which he invokes for guidance in his philosophical enquiries, do resemble preliminary and uninvestigated judgements, rather than anything easily correlated with his conception of phantasia.$^{13}$ And even in perceptual cases, Aristotle himself does not always maintain his dokein/phainesthai distinction. In De Insomniis, he remarks that to those on board ship the land seems (dokei) to be moving (460b26-7); startlingly, he also says that even to healthy people who know better, the sun still seems to be (einai dokei) a foot across (458b28-9). Such slips support the view of the judgemental account that the phainesthai/dokein distinction can only be one of degree between less and more powerful inclinations of judge. If the person on deck experiences no inclination at all to judge that the land is moving, he will surely say, in the manner of Anaxagoras, that it does not appear to him to do so. If I am prepared so say that the sun appears a foot across, it is because of some inclination to think it so - an inclination the Platonist can interpret as an actual, but low-level or preliminary judgement. ${ }^{14}$

\section{III.}

It is at least superficially the non-judgemental Aristotelian conception of phantasia which carries the day in later epistemologies. Epicureans and

${ }^{13}$ E.g., EN 1145b2-7. On Aristotle's conception of phainomena in these contexts, see G.E.L. Owen, "'Tithenai ta Phainomena'", in Articles on Aristotle vol. 1, eds. Jonathan Barnes, Malcolm Schofield and Richard Sorabji (London, 1975), pp. 113-26 (first published 1961); Jonathan Barnes, "Aristotle and the Methods of Ethics", Revue Internationale de Philosophie 34 (1980), pp. 490-511; and Terence Irwin, Aristotle's First Principles (Oxford, 1988), esp. Ch. 2.12-19. Note especially Barnes p. 491n.1, and Irwin pp. 30-1, pp. 37-8 on the judgemental character of such phainomena.

${ }_{14}$ Thus the judgemental account can easily explain why modern educated people in fact tend to be reluctant to make this appearance-statement. Anyone who has difficulty believing that it could ever have been a judgemental appearance-statement is referred not only to Epicurus (see section III) but to Josef Skvorecky's novel The Engineer of Human Souls, for an impassioned debate between two Czech peasants as to whether the full moon is the size of a round loaf of bread or a prewar five-crown piece (New York, 1984, pp. 86-7). 
Stoics both sharply distinguish between an 'impression' (phantasia) and a judgement as to how the world is. At the same time the relations of phantasia and phainesthai/phainemonon become less clear. The explanation is perhaps the problem already noted with Aristotle's account: to the extent that a sharp line is drawn between the impression and the judgement, then some appearances, those which in bios seem to be judgemental, will correlate with the latter. So as a non-judgemental conception of impressions becomes increasingly central to philosophical accounts of thought, phainesthai/phainemonon will tend to become an ambiguous and unhelpful concept.

In Epicurus' theory, Sextus reports that "of two things which are paired with each other, impression (phantasia) and judgement (doxa), the impression, which he also calls evidence, is invariably true" ( $A M$ 7.203, cf. $A M$ 8.63, Plutarch ad. Col. 1109a-b). Judgement is distinct from and additional to phantasia; the latter seems to be something very close to the image received from the senses. The phantasia is true because sensation mechanically records the eidola received from an object. It is with the judgements that we pass on its basis that error may arise (Ep. Hrdt. 50). ${ }^{15}$

Now as this indicates, the Epicurean impression must differ from the Peripatetic. Epicurean impressions are presumably less determinate in their content: otherwise we could avoid all error simply by assenting to all of them. It is reasonable to suppose that the Epicurean impression requires a significant degree of further interpretation (with a significant opportunity for error) to yield propositional claims. ${ }^{16}$ Although this is not explicit in Epicurean writings, it is notable that sensation is characterised as alogos, which besides imputing a general lack of rationality means, literally, without speech (DL X.31, SE $A M$ 7.210, $A M$ 8.9). This suggests, what the existence of human error confirms, that the content of our impressions may not be directly and clearly accessible to us.

${ }^{15}$ Gisela Striker argues that phantasia only joins or replaces aisthêsis in the slogan 'All perceptions/impressions are true' in later accounts of Epicurean views, under the influence of Stoic terminology ("Epicurus on the Truth of Sense Impressions", AGP 59 (1977), pp. 125-142; see esp. pp. 126-7). This possibility does not seem to me to affect the issues I am concerned with here; at any rate the basic contrast between the phantasia and what is added by opinion is already present in Ep. Hrdt. 50. Cf. also C.C.W. Taylor, “" 'All Perceptions are True' ", in Doubt and Dogmatism (op.cit. n.1), pp. 105-24, and Elizabeth Asmis, Epicurus' Scientific Method (Ithaca, 1984), Ch. 8.

${ }^{16}$ Cf. Striker (op.cit., n.15), who distinguishes between the Stoic belief that there is "a kind of automatic translation" of impressions into propositions, and the apparent Epicurean suggestion "that our perceptual judgements are sometimes interpretations rather than translations" (p. 134). 
So the relation of an Epicurean impression to how one might say things appear is problematic. If the Epicurean wants to preserve the correlation of appearance with (infallible) impression, then things will always be as they appear to him; but it may be difficult for him to say how that is. In fact, his particular 'appearance-statements' will really be reports of his judgements, judgements at once regarding the content of his impressions and the facts of the matter. Given the need for interpretation of our impressions, what 'appears' to us may be understood either as the genuine content of our impression (call this appears $_{\mathrm{p}}$ ); or as what we take that content to be (appears $\left.{ }_{d}\right) \cdot{ }^{17}$ It is the former which is really of interest to the Epicurean, as it seems to offer a firm foundation for our judgements. But it is difficult to see how we can gain the direct access to this appearance necessary to express it in our appearance-statements.

Thus Epicurus' use of appearance-language is ambiguous. It is in his discussion of the heavens that Epicurus makes the most use of appearancelanguage; and here ta phainomena are primarily the observational data which scientific explanations seek to explain and with which they must be compatible (e.g., Ep.Pyth. 87, 92, 97, 98). This is, so far as I can tell, ambiguous between appears and $_{\text {appears }}$; it is in any case unrevealing given that this usage was part of common astronomical parlance (Eudoxus wrote a book on ta phainomena). ${ }^{18}$ A more striking use of phainetai is Epicurus' claim that the sun, along with the other heavenly bodies, is more or less the size it 'appears' - that is, predictably, about a foot across. ${ }^{19}$ Now if 'appears' in this claim is taken to be appears $s_{p}$, it is boringly and unhelpfully true for the Epicurean: everything is the size it appears $s_{p}$, for the senses do not lie. For the point to be worth making, 'appears' must be understood as appears $_{d}$ : it must express what the mind unreflectively takes to be seen by the senses, presumably incorporating the interpretation which it standardly imposes. So the claim that the sun appears a certain size expresses the

${ }^{17}$ So, as Lucretius asserts, error arises "propter opinatus animi quos addimus ipsi/pro visis ut sint quae non sunt sensibu' visa" (IV.465-6); cf. Cicero Acad. Il.xxv.80.

${ }^{1 *}$ See Lasserre, François (ed.): Die Fragmente des Eudoxos von Knidos (Berlin, 1966), p. $39 \mathrm{ff}$.

${ }^{14}$ See Ep. Pyth. 91, Lucretius V.564-591, Cicero De Fin. I.vi.20, Acad. Il.xxvi.82, cf. II.xxxix.123, etc. The size of the sun becomes a topic of ongoing debate between Epicureans and their adversaries. See Philodemus De Signis, cols. ix-xi for the dialectic; for Posidonius' views, see F9, F19, F115, and F116, in L. Edelstein and I.G. Kidd (eds., commentary), Posidonius (2nd edn., Cambridge, 1989). Cicero reports the Stoic position as being that the sun is 'more than nineteen times' as large as the earth (Acad. II.xli.128, cf. II.xxvi.82). 
acceptance, not of an impression which makes that claim, but of the standard interpretation of the relevant impression. (This use of 'appears' turns out to be quite compatible with a judgemental account of appearances, since the interpretation can be identified with the passing of a preliminary judgement.) If our judgements are correctly formed, they will be identical in content with the impressions on which they are based, without 'adding' or 'subtracting' anything; but they cannot quite be the same things. Accordingly the Epicurean derives his views not just from raw perceptual data but from investigation and argument; and his claim is that their results confirm our standard preliminary judgement about the size of the sun. ${ }^{20}$

On the other hand, it seems that in cases in which 'appearances' are deceptive, the Epicurean does not want to allow them to count as appearances at all. For example, a critic objects that the Epicurean is committed to the following reasoning: "Since everything which appears also is (pan to phainomenon kai esti), and the sun appears to stand still, the sun is standing still." The Epicurean response: "We will say to this what we also said before, that the sun does not appear to stand still, but is judged to (so) appear (dokei de phainesthai) . . .". ${ }^{21}$ Here it is clearly appearances ${ }_{p}$ which are at stake. All of them, like all impressions, are true (cf. Sextus, $A M$ 7.369); our task is to distinguish these appearances and impressions from the fallible judgements which latch on to them.

IV.

By the time of Epictetus, the Stoic conception of phainomenon is closely associated not only with phantasia but with the other concepts tied to it in Sextus Empiricus.

"What is the cause of assent to something? That it appears to be the case (to phainesthai hoti huparchei). So assent to what appears not to be the case is impossible. Why'? Because this is the nature of thought, to approve what is true, to be dissatisfied with what is false, and to suspend judgement regarding what is non-evident (pros ta adela epechein). What is the proof of this? Feel (pathe), if you are able, that it is now night. - Impossible." (Discourses 1.28.1-3, cf. III.3.2, III.17.15, III.22.42)

20 The central investigative procedure relevant to our perceptions of celestial phenomena is comparison with terrestrial phenomena: see Ep. Pyth. 87, Ep. Hrdt. 80, and for its application to this case, Lucretius V.564-91 and Philodemus de Signis, cols. ix-xi.

21 PHerc. 1013, col. xx, following the text of Constantia Romeo; "Demetrio Lacone sulla grandezza del sole (PHerc. 1013)", Cronache Ercolanesi 9 (1979), pp. 11-35 (p. 20). Cf. the discussion in Asmis (op.cit. n.15), to which I owe this reference. 
Similarly Epictetus cites 'the philosophers' as saying that there is a single starting-point (archê) for everyone: "in the case of assent, the feeling (to pathein) that something is the case; and of denial, the feeling that it is not the case; and, by God, of suspending judgement, the feeling that it is non-evident" (Discourses I.18.1). His concern is with the implications of these features of thought for human action. One is that "for a person the measure of every action is the apparent (to phainomenon)" (I.28.10). "So that even such great and terrible deeds have this starting-point, the apparent? - This and no other. The Iliad is nothing but impression (phantasia) and the use of impressions." (I.28.11-12) Agamemnon and Achilles followed the appearances: the apparent is the starting-point of every tragedy (I.28.31-3).

As I.28.11-12 makes plain, impression and appearance are correlatives of a sort. Yet the Stoic conception of impressions is as prior to acts of judgement; and the appearance seems to be judgemental, since we act on the basis of what appears (I.28.10, 31-2). The two can still be awkwardly correlated by conceiving of the appearance as the component of the impression sustained in judgement. The claim that we assent to what appears (I.28.1) suggests that the appearance is the persuasive content of the impression, that which induces assent to it when we do assent. This rather ambiguous view is made more natural by the view that impressions commonly do have a strong enough persuasive element to cause assent. Thus Epictetus insists that we must struggle and train ourselves to resist giving assent to our impressions (Discourses II.18.23-32, III.8). The view is compactly expressed at Encheiridion 1.5: whenever we meet with a harsh impression we are to say to it " "phantasia ei kai ou pantôs to phainomenon": "you are an impression and not at all the apparent (i.e., not at all what appears to be the case). "22 This constitutes resistance to an impression; to deny that it is 'apparent' is to reject its persuasive force. The persuasive

\footnotetext{
22 To phainomenon here has been variously translated, e.g. as "what you appear to be" (trans. W.A. Oldfather, Epictetus (Loeb Classical Library, 1928), vol. 2, p. 485), and "the thing that has the appearance" (trans. Nicholas White, Handbook of Epictetus (Indianapolis, 1983), p. 12). Neither seems to me satisfactory: the first is unclear (what is it that the phantasia appears to be but isn't?), and the second involves taking to phainomenon as in effect equivalent to to hupokeimenon or to on. It seems to me more likely that Epicurus is here using to phainomenon in a strongly judgemental sense, as he often does - cf., besides the passages quoted above, para to phainomenon for "contrary to his opinion' at Discourses IV.1.147 (cf. IV.1.55), and to phainomenon dikaion for 'what seems to me right' at I.2.21.
} 
force of impressions also creates a certain parallel between phainomena and impressions which perhaps helps to blur the asymmetry between the two. One normally gives in to an impression and accepts it - unless it encounters some opposition, so that one is obliged to investigate and select. Likewise, judgemental phainomena are the comparatively unreflective views that one is likely to abide by as long as nothing interferes and no investigation is undertaken.

The concepts Epictetus employs in relation to phantasia are the same as we find in Sextus Empiricus: assent and suspension of judgement, the apparent, the non-evident, feeling (pathos), etc. Besides the relation of phainomenon to phantasia, three points about Epictetus' views seem to me particularly significant for the interpretation of Sextus. The first is that the basis of assent can be expressed indifferently as "the appearance that something is the case" (Discourses I.28.1-2) and "the feeling (to pathein) that something is the case" (I.18.1, cf. pathe at I.28.3). As this suggests, 'feeling' can be a somewhat misleading translation of pathos or to pathein. It is quite clear that a pathos can have cognitive content - recall too Plato's reference to his judgemental phantasia as a pathos at Sophist 264a5. So expressions of pathê may presumably be on an equal footing with other claims expressing our beliefs and judgements about the world.

Second, Epictetus' schema of our responses to impressions is very close to what we encounter in Sextus. Like Epictetus, Sextus employs a dichotomy between what appears and what is non-evident, assenting to what appears and suspending judgement regarding what is non-evident $(\mathrm{PH}$ 1.13-4, 1.19-20, 1.193, DL IX.103). (Perhaps Epictetus' third option, the rejection of an impression, can be dropped without loss, as tantamount either to suspension of judgement or to assent to the contrary impression.) In both writers, the whole process sounds almost automatic. Epictetus says that thought is by nature such as to respond with assent to the apparent, with suspension of judgement to the unevident. Sextus likewise tends to speak of epochê as something that simply happens when opposing grounds for belief appear of equal strength, and he emphasises that the sceptic's assent is given under compulsion ( $P H$ 1.13, I.19, 1.193). So, like the sceptic's reliance on pathos-language, his claim of compulsion need not be interpreted as something peculiar to him or dependent on the specifically sceptical character of his thought. (We may nonetheless reasonably ask for an explanation of the sceptic's emphasis on these themes: I offer one in sections VI-VII.)

Finally, I want to note a particularly revealing use of dogmata, in Dis- 
courses III.16. ${ }^{23}$ Here Epictetus, as usual chastising his students for moral slackness, discourages them from association with the common run of unphilosophical people (idiotai). He warns that - unless they have the extraordinary power of a Socrates to reform those around them - they will themselves be corrupted by such association.

\begin{abstract}
"Why then are they (the idiôtai) stronger than you? Because this garbage they blather comes from dogmata, and your clevernesses come from your lips. Because of this it's slack and dead, and anyone who hears your exhortations and the miserable virtue you keeping droning on about is revolted. So the idiôtai defeat you. For dogma is everywhere strong, dogma is invincible. So until your clever notions are fixed in you and you've got some power to keep you safe, I warn you to be cautious about descending to the idiôtai." (Discourses III.16.7-9)
\end{abstract}

The dogmata which the idiôtai have, and which Epictetus' students lack, are strong, stably held ('fixed') judgements able to resist opposition and consistently guide action. Although this use does not quite conform to either of Sextus' sense of dogma (see section V on $P H$ 1.13), I think that it sheds some light on the sceptic's general rejection of the dogmatic. For example, it helps to explain what is shared by two kinds of belief which the sceptic must reject: the dogmatist's philosophical tenets and the ordinary person's convictions about matters of value. ${ }^{24}$ Both count as dogmata in Epictetus' sense; and this sense captures the features of ordinary beliefs about value that make them a source of anxiety and so undesirable. On this point too, Epictetus comes very close to Sextus: compare Epictetus' view that it is our dogmata which distress (tarassei) us (Discourses 1.19.8) with Sextus' description of the goal of scepticism as freedom from distress (ataraxia) in matters of judgement (en tois kata doxan, $P H$ 1.25).

$V$.

For Epictetus, some truths can be guaranteed by cataleptic impressions; for Sextus, who views this 'criterion' as a central instance of dogmatic assertion

${ }^{33}$ Barnes 1983 (op.cit. n.1) provides a valuable survey of uses and senses of dogma (pp. 16-22). His general conclusion is that "a man's dogmata are what dokei to him, the things which seem good or right. But the word has a distinctive colouring. derived from its public use: the colouring is that of weight and practicality." (p. 22). What this passage shows is that this colouring of 'weight' can be all-important: what Epictetus' students lack is not judgements per se (they probably have all too many), but judgements of sufficient weight.

${ }^{24}$ On the sceptic's rejection of the latter, see Frede 1979 (op.cit. n.3). p. 198; Barnes 1983 (op.cit. n.1). p. 31 n.86; and Burnyeat 1984 (op.cit. nr.1), pp. 241-2. 
about the non-evident, nothing is ever known. In the remainder of this paper I will try to sketch a judgemental interpretation of the sceptic's utterances which can accommodate this opposition to dogma, and suggest some problems to be faced by any non-judgemental account.

There seem to be three standard forms of sceptical utterance available on any particular subject. One form of utterance expresses assent to an appearance: 'I seem warm', or 'It is day' (with the constant caveat that 'is' means 'appears', $P H$ 1.135). Second, the sceptic may report his epochê regarding an adêlon: 'I suspend judgement as to whether the earth is spherical'. Sextus explains the content of such pronouncements as follows: "We adopt 'I suspend judgement' in place of 'I am unable to say which of the things presented I should believe (pisteusai) and which disbelieve, making it clear that the matters appear to us equal with regard to credibility (pistis) and incredibility." ( $P H$ 1.196). Third, the sceptic may combine the two: "honey appears sweet to me, but whether it is sweet in reality is a matter for investigation' - and such investigations invariably terminate the epochê (PH 1.20).

Now these types of utterances may be presumed to be formally on a par, for we are told by Sextus that everything he says is to be understood as an appearance-statement. In $P H 1.4$ he announces his intention in what follows to "report about each thing, like a chronicler, on the basis of how it presently appears to us", thus bringing the whole content of $P H$ under the heading of appearance (cf. $P H$ 1.135). Now, according to $P H 1.19$, the sceptic's appearance-statements report the contents of impressions to which he is compelled to give assent:

"For we do not overturn the things which lead us involuntarily to assent in accordance with an affective impression (pathêtikê phantasia), as we said before: and these are the appearances." $(P H 1.19)$

What he 'said before' is this:

"We say that the sceptic does not dogmatise, not in the broader sense in which some say it is dogma to acquiesce in some matter - for the sceptic assents to compelling experiences (pathê) in accordance with an impression (phantasia); e.g.. he would not say, when warmed or cooled, 'I seem (dokô) not to be warmed or cooled. Rather we mean 'not dogmatise' in the sense in which some say dogma is assent to some matter among the non-evident objects of investigation by the sciences. For the Pyrrhonist assents to nothing non-evident." (PH 1.13, cf. $P H$ 1.193)

What the sceptic assents to is rather oddly distinguished from the impression itself. In $P H 1.19$, the sceptic assents to the appearances, in $P H 1.13$, to pathê, both times 'in accordance with' or perhaps 'on the basis of' (kata) an impression (cf. $P H$ 2.10). But whatever the exact sense of kata here, this 
assent may represent much the same sort of judgement as Epictetus might pass. For in $P H$ 1.19 Sextus, like Epictetus, seems to use phainomena for the persuasive, assent-causing content of the phantasiai. ${ }^{25}$ (This use allows the sceptic to obliterate the Aristotelian contrast between phainesthai and dokein in $P H$ 1.13: given that this too must refer to an appearance-statement, how things appear to the sceptic is not differentiated from how they 'seem' to him to be.)

So the sceptic's utterances are to be associated with both the appearances and the impressions which are the basis of his assents. These utterances will include his reports of suspensions of judgement; these are, I suppose, assents 'compelled' in accordance with the impression that opposing arguments are of equal strength. (The sceptic will not positively affirm that they are equal, but will say that they appear so to him (PH 1.196).) Thus the sceptic's second kind of utterance is, as implied in $P H 1.4$, an appearancestatement as much as the first. And the third kind of utterance is simply a combination of the first two in a single situation: as I understand it, the sceptic is compelled to assent both to a particular appearance and to the equal strength of the evidence supporting and opposing it.

On the judgemental interpretation, the sceptic's utterance ' $P$ ', or 'It appears that $P$ ' reports his tentative and preliminary judgement that $P$. The sceptic is compelled to assent that $P$; but he recognises that further investigation may not confirm his view, and he marks this recognition by the use of appearance-language. His utterance, 'I suspend judgement as to whether $P$ ' reports that, now that he has investigated $P$, he judges that the arguments for and against it are of equal strength. (Of course this will still only be a tentative and preliminary judgement, since - for one thing - each of the grounds given for and against $P$ could itself be made the object of investigation, and suspension induced regarding it). His admission that 'It appears that $P$, but as to whether it is so in reality I suspend judgement' reports the concurrence of these two cases. The possibility of such concurrence obviously implies that the sceptic's assent to the appearance that $P$

${ }^{25}$ Two remarks should be noted which might seem to undermine this reading of 'appearance'. Sextus at one point says that by phainomena he 'now' means perceptions (aisthê$t a)$, as opposed to thoughts (noêta) (PH 1.9). But this is clearly marked by the 'now' as a special sense (one which a judgemental interpretation, by granting paradigmatic status to perceptual information, can easily accommodate). More significantly, $P H 1.19$ may seem incompatible with $P H$ 1.22: in the latter, a phainomenon is 'virtually' (dunamei) equivalent to phantasia, with no mention made of assent. But on the interpretation offered here of $P H 1.19$, the dunamei could be intended to allow for just this restriction to the assent-compelling content of phantasia. 
may be detached from his views about the strength of the arguments available on that subject. But (as I will argue in section VII) this does not imply that sceptic's assent is not to a judgemental appearance, nor even that he is incoherent.

It seems to me that this understanding of the sceptic's discourse is supported by the results of the earlier discussions noted. For what emerged there was that to the extent that 'the apparent' is the prominent concept, and the 'impression' primarily what correlates with it (as in Plato), appearance-language is to be understood judgementally. And to the extent that the focus is rather on a non-judgemental philosophical conception of impressions (as in Aristotle and the Epicureans), the concept of appearance tends to become ambiguous or marginalized. Giving prominence to both generates a conception of the appearance as the persuasive content of the impression: in effect, a judgemental understanding of everyday appearance-language must be grafted on to a non-judgemental conception of impressions (Epictetus). Now the sceptic can have no interest in contributing to the quintessentially dogmatic project of specifying the true nature of impressions; still less is he likely to favour a philosophically sophisticated account of (non-judgemental) phantasia over an everyday conception of appearance. In any case, with Sextus it is clearly the latter notion which is primary. The sceptic adopts the language of appearances as an undogmatic way of talking about the world; to the extent that he speaks of impressions in his own voice it is just as an intentionally rough and indefinite correlative to these appearances. Thus the sceptic returns to the Platonic notion of the apparent as what one may take in a preliminary and tentative way to be the case - not qua Platonic, of course, but as the view implicit in our everyday use of appearance-language.

I now want briefly to point out some difficulties with the non-judgemental line of interpretation of Sextus' appearances. Sextus' reliance on pathos-language provides an opening for such interpretations; for a pathos seems to fall within the realm of subjective experience, and often applies to non-judgemental experiences, such as medical conditions. So the sceptic's reports or expressions of his pathê could perhaps be understood as purely autobiographical, subjective records of internal events. Now we have seen that a Platonic judgemental phantasia and an Epictetan judgemental appearance, which clearly make claims about the outside world, can equally be called pathe. But the status of reports on such pathê is still ambiguous, and not simply because of the peculiarities of the Greek term. In English as well, if I say, 'My feeling is that $p$ ', it may be unclear as to whether I want to tell you about the world or about myself, or both. The real significance of 
such statements seems to be dependent on the context and the speaker's intention.

But, in support of the judgemental account, it will be noted that such comments are usually offered not as autobiography but as a diffident contribution to a discussion on whether $p$ is in fact the case. (And, obviously, no degree of diffidence can by itself make such comments any less judgemental.) Further, it can be argued that the 'autobiographical' use of such statements is not only parasitic on the world-related use but even incorporates it. For even if I report my feeling that $p$ solely for the joy of talking about myself, what I say about myself is that I believe $p$-believe it to be true of the world. For me to 'have a feeling that $p$ ' is for me to believe that $p$ is true; in reporting my belief in this manner I simply express my refusal or inability to offer you any particular reason to share it. A nonjudgemental interpretation of reports of this kind would depend on confounding the speaker's emphasis and purpose with the actual content of the report.

Of course it might be that, regardless of the content of pathos-reports in bios, those of the sceptic are intended as wholly autobiographical and somehow free from world-related assertion. A crucial text for this line of argument is $P H 1.22$, in which Sextus explains his use of the appearance as practical criterion:

". . . so calling what is virtually the impression (phantasia). For lying in passive affection (peisis) and unwanted feeling (pathos) it (i.e. the phantasia) is not an object of investigation (azêtêtos). Hence perhaps no one argues about whether what is underlying appears (phainetai) this way or that; what's investigated is rather whether it is such as it appears." $(P H 1.22)$

Much has been made of the word azêtêtos here: "There is thus a large class of statements which, as Sextus puts it ( $P H 1.22)$, are immune from enquiry (azêtêtos) . . . because they make no claim as to objective fact. They simply record the sceptic's own present experience ...".26 "The involuntary awareness of affection is what Sextus is pointing to when he calls them indisputable and not open to question (azêtêtos) ... One cannot deny experiencing what one is experiencing. But that just means that affections are not the sorts of things that are intelligibly disputed." 27 Sextus' experiences of appearances are excluded from investigation; his statements, by applying only to this special realm, inherit its peculiar and privileged status - which somehow exempts them from any taint of dogmatism.

26 Burnyeat 1982 (op.cit. nr.1), p. 26; cf. 1980 (op.cit. n.1), p. 36.

27 Stough (op.cit. n.1), p. 149. 
However, the description of the sceptic's impressions as azêtêtos need not have any such implications. For one thing, azêtêtos need not mean 'not susceptible of investigation'; it can just as easily mean simply 'uninvestigated'. In its other occurrences in Sextus (which are rather few and insignificant) azêtêtos seems to be used in the latter sense, to describe something which happens, as a matter of contingent fact, not to have come under investigation $(A M 2.112,8.347,10.14)$. And this seems to be a common usage.$^{28}$ In any case, as I will argue in section VI, the judgemental account can allow for the sceptic's appearance-statements to be formally excluded from investigation in a limited respect; but this limited exclusion implies neither any privileging of subjective experience nor any abstention from world-related assertion on the part of the sceptic.

All non-judgemental interpretations of the sceptic involve drawing a sharp contrast between expressions of experience and claims about the world; taking the sceptic to engage solely in the former, they proceed to draw out implications for the cognitive status and linguistic force of his statements. According to M.F. Burnyeat, the sceptic's appearance-statements are 'non-epistemic' experiential reports which as such do not count as true or false. ${ }^{29}$ In the ancient context, and for Sextus in particular, truth always has reference to a real objective external world, contrasted with subjective experience: thus "statements recording how things appear cannot be described as true or false, only statements making claims as to how they really are." ${ }^{30}$ Since to believe something is to accept it as true, belief has no application to sceptical appearances either.

The disadvantage of this interpretation is of course that it seems to commit the sceptic to a considerable degree of dogmatism, supposedly unrecognised as such. For the distinction on which it rests, between internal subjective experience and external world, is itself theory-laden. The sceptic's position would resemble that of the Cyrenaic school, who are indeed

${ }^{28}$ Galen, always an interesting point of reference for Sextus, cites Erasistratus as saying: "So it is right for one who wants to give correct medical treatment to be exercised in medical affairs, and not to let any of the symptoms occurring in connection with a condition (pathos) go uninvestigated (azêtêton apheinai), but to examine and make it his business, according to which disposition each of them occurs." (De Atra Bile 5.138.6-9) Here medical symptoms are azêtêta just in case they are not in fact investigated by the doctor; Erasistratus' injunction implies that they are indeed appropriate objects of investigation. Cf. also azêtêtos at De Praen. ad Post. 14.639.7, Heliodorus Aethiop. 1.33.4.2, and Justin Martyr Apol. 68.7.2.

${ }^{29}$ See in particular Burnyeat 1980, pp. 25-7; 1982, pp. 25-6; 1984, p. 243 (opera cit. n.1).

${ }^{30}$ Burnyeat 1980 (op.cit. n.1), p. 26. 
discussed by Sextus as one of the 'neighbouring' schools to scepticism ( $P H$ 1.215, cf. $A M 7.190-200$ ). The Cyrenaic claims infallible knowledge of his own pathe $\hat{e}$, but not of what they come from: the gulf between private internal experience and external world is unbridgeable ( $A M$ 7.194-6). The appearance-statements of a Cyrenaic-sceptic would likewise deal exclusively and authoritatively with the former, though presumably Cyrenaic-sceptics, unlike the Cyrenaics, would not avow knowledge of their experiences. ${ }^{31}$ The problem is that we would further expect thoughtful and thoroughgoing sceptics to disavow as dogmatic the loaded dichotomy on which the Cyrenaic view is based. In particular, we may reasonably suppose the sceptics to have been alert to the dogmatic character of any conception of 'subjective experience' as a zone specially exempt either from truth-claims or from debate. After all, our 'impressions' belong to subjective experience if anything does, and every aspect of their character is for the sceptic a preeminent subject of debate. Claims about the impressions one experiences can be made dogmatically or undogmatically, and the difference between the two cannot be correlated with any given boundary between the self and the world. Part of the Stoic's conception of cataleptic impressions is that they are adequately distinguished from non-cataleptic ones by purely internal characteristics, as horned snakes are from other snakes ( $A M$ 7.252). That we not not always succeed in recognising this feature of the impression is beside the point; the problem is to see how a Cyrenaic-sceptic could legitimately argue against a Stoic's claim to do so, or characterise such a claim as dogmatic.

A different elaboration of the non-judgemental interpretation of the sceptic is offered by Jonathan Barnes. Barnes emphasises that in making his characteristic utterances the sceptic is performing a peculiar sort of speech act:

\footnotetext{
"Adults, when they are in pain, may utter the sentence "I am in pain" (or some vulgar equivalent): they thereby express their pain, but they do not (according to Wittgenstein) state that they are in pain (they state nothing at all). The Pyrrhonist of $P H$, when he is mentally affected, may utter the sentence, 'The tower seems round': he thereby expresses his pathos, but he does not state that he is experiencing a certain pathos (he does not state anyting at all). ${ }^{n 32}$
}

The sceptic's appearance-statement is something akin to a Wittgensteinian 'avowal', and so presumably must be produced "as a direct and natural response to external stimuli", ${ }^{33}$

${ }^{31}$ As is confirmed by Galen's reference to "oafish Pyrrhonists who say that they do not securely know their own pathê" (De differentia pulsuum IV, 8.711).

${ }^{32}$ Barnes 1983 (op.cit. n.1), p. 14.

${ }^{33}$ ibid., p. 15 n. 30. 
The 'phenomenological' interpretation of Sextus has the advantage that it construes the sceptic as unequivocally avoiding dogmatism, by bypassing assertion altogether. However, just as we may wonder what the metaphors of 'striking' and 'impressing' amount to, we may wonder how an 'avowal' or 'the expression of a pathos' is to be positively understood. The model of stimulus and response is also unclear in its implications; but it seems to involve likening the elaborate processes of argumentation engaged in by the sceptic to an immediate physical stimulus, such as a stab of pain. But are we to suppose that this is how the sceptic conceives of human cognition and utterance in general? Surely for him to do so would be dogmatic (to the extent it is meaningful) in itself; it would also suggest his utterance to be no less dogmatic than the norm. Is there rather something special about the basic cognitive processes of the sceptic? This seems absurd - after all, he spends much of his time rehearsing arguments originally thought through by others. Like the original metaphors of 'striking' and 'impressing', the simile of pain-behaviour seems to become either highly implausible or simply vacuous when extended to the full range of the sceptic's discourse. And the attribution of a non-assertoric, 'expressive' use of language to the sceptic seems to me in principle undesirable. Not only is it very far from bios (unless you are Wittgenstein), but it must debar $P H$ from having the normal force of explanations and arguments. The sceptic will simply be someone who, experiencing a distinctive series of private, subjective impressions, 'expresses' them in his non-assertoric idiolect. But then it is hard to see why the dogmatist should attent to the sceptic's performance, or how genuine philosophical conflict wil be possible between two.

In sum, the claim that one enjoys 'experiences' by nature exempt from dispute is one that could only be made by a dogmatist armed with a particular sort of psychological theory. To use such a claim to designate one's utterance as both inarguable and undogmatic would imply further dogmatic claims regarding the nature of those utterances and their relation to experience. The sceptic should be the last person to make all these claims; and, I suggest, Sextus does not make them. In the following sections I will try to show how, on the other hand, a sceptic who engages in reporting on wholly judgemental appearances can do so both undogmatically and in conformity with bios.

$V I$.

To understand the sceptic's judgements we need to look more closely at the notion of 'investigation'. Sextus' introductory characterisation of the scep- 
tic is as one who, in contrast to both dogmatics and Academics, continues to investigate or search for (zêtein) the truth (PH 1.2-4). He is the dedicated practitioner of zêtêsis, investigation; one of the alternative names for 'sceptic' is 'zetetic' ( $P H$ 1.7). Now the sceptic's investigation takes place in a particular dialectical context. The appearance-reality distinction is itself entrenched in bios. But by the time the sceptic appears on the stage, the distinction has been seized upon and transformed by the dogmatic philosophers. Bios admits that what appears green in a certain light may really be blue; the dogmatist claims that colour phenomena as a whole are only apparent. Bios notes that when we sail past land, it seems to move; the dogmatist claims that all motion is unreal. The dogmatist takes the everyday distinction between apparent and real, made in particular cases and with regard to particular respects, and applies it to some general feature of experience, creating an opposition in which the whole pre-dogmatic realm is cast as appearance. In bios, the apparent is what has yet to be confirmed by procedures of investigation (calculating, weighing, measuring). The dogmatist is someone who has a specially privileged procedure of investigation, involving the application of his philosophical knowledge. The dogmatist thus views any results obtainable otherwise, the findings of bios, as merely preliminary and defeasible, and so merely a matter of appearance.

In this context, what does it mean for the sceptic to be a follower of appearances and a partisan of bios? The sceptic cannot simply be someone who confines his claims to the realm of appearances, for this is not an autonomous region. The claims of the dogmatist are not of some specialized kind compatible with those of bios, but may directly confirm or conflict with everyday claims. ${ }^{34}$ The ordinary person may affirm, 'It is day' under appropriate conditions without reflection. The dogmatist will make or reject exactly the same assertion, depending on the presence of the conditions which license such a judgement (e.g., a cataleptic impression that it is day). Now the sceptic has investigated and rejects the reasoning which grounds the dogmatist's theory, but he cannot - as long as his search for the truth continues - dismiss the possibility that some such dogmatic account is correct. And to do that is to allow for an irreducible possibility that even the most innocuous of everyday claims, such as 'It is day', are simply false. At the same time, the sceptic experiences the irresistible impression that it day; he is compelled to assent that it is so. In doing so he might seem to be siding with bios; but in leaving room for a true dogmatic theory to the

${ }^{34}$ Cf. the discussion of 'insulation' in Burnyeat 1984 (op.cit. n.1). 
contrary - in suspending judgement 'as far as it's a matter of argument (epi tôi logôi)' - he departs from it. And he marks this departure by saying not that it is, but only that it appears to him to be day. As he thereby indicates, his judgement is eminently preliminary and defeasible (he does not deny the dogmatist's charge to this effect); indeed he continues his search for a procedure of investigation which might lead to its defeat.

So in assenting to his 'appearance' the sceptic passes a preliminary judgement, and he uses the language of appearances to express his recognition of its character. The sceptic's language suggests that we should consider the idea of 'judgement' more closely. Several terms in the sceptical vocabulary have political or legal connotations, and the sceptic's judgemental process can find counterparts in processes of legal and political deliberation. The usual term for assent is sunkatatithemai, the basic sense of which is 'to vote along with' (see LSJ s.v.). Further, according to Diogenes Laertius, the sceptic's answer to the charge of dogmatism includes the following admission: "that it is day and that we live and many other appearances in everyday life we judge (diaginôskomen)" (IX.103). So to assent to an appearance is to diagignôskein it; and diagignôskô can mean, as a law-term, to determine, decide or give judgement (LSJ s.v.). It is also interesting that, according to Sextus, Carneades used the metaphor of the public scrutiny of political candidates for the testing of concurrent impressions ( $A M$ 7.182). Further, Sextus' sceptic has dogmata in the sense that things eudokein tini pragmati, and he will not deny how they seem (dokein) to him ( $P H$ 1.13). Now as Jonathan Barnes has rightly stressed, the verb dokein was early used for political resolutions; and "dogma, in its earliest surviving occurrences, has a political colouring: a dogma is what dokei to an offical or to an authoritative body; it is a decree or a resulution ... throughout its history it appears frequently in political or semi-political contexts". ${ }^{35}$ And by Sextus' time, the very name for his activity, zêtêsis, had a sense of 'judicial inquiry' (LSJ s.v.).

Suppose that the sceptic thinks of himself as a juridical or political body engaged in the consideration of information and the passing of appropriate judgements or verdicts. ${ }^{36}$ These verdicts are assents to appearances; their contents are recorded in the sceptic's appearance-statements. Often such

${ }^{35}$ Barnes 1983 (op.cit. n. 1), p. 16.

36 My claim is not that this model is peculiar to the sceptic: it seems natural to assimilate epistemic to political deliberation. Perhaps such assimilation can already be seen in Plato's reference to procedures of investigation as preventing the apparent from 'ruling' (archein) in our souls, at Republic 602d7. 
judgements incorporate or imply a resolution as to what is to be done; accordingly the appearances are the sceptic's practical criterion. Now this model suggests that a modification of the judgemental account of appearances is in order. For the judgemental appearance-statement 'It appears to me that $P^{\prime}$ can now be read as $\left(P^{*}\right)$ : 'I judge (find, deem), on the basis of my preliminary information, that $P$ '. And statements introduced by 'I judge that . . ., 'I find that . . ', or 'I deem that ...' do not quite have the force of standard assertions about the world. Rather, they record decisions or results. If we interpret the sceptic's appearance-statements as expressions of 'judgements' in a strict sense, their force should be similar: while they do incorporate assertions, they are something more and formally something different.

This special character of appearance-statements enables Sextus to use them without either taint of dogmatism or any loss of assertoric force. The content of the judgement he expresses, $P$, is a claim about the world and is clearly subject to further debate. But $P^{*}$, assuming it to be the report of a duly passed 'verdict', is in a sense inarguable. For it is quasi-performative in character: if the jury says 'Guilty' in the appropriate fashion, then it indisputably does find the defendant guilty. Understood as verdicts, appearance-statements cannot quite be subject to contradiction; they may only be reviewed, revised and overruled. Indeed, since the language of appearance points to the preliminary character of the judgement being expressed, it emphasises the possibility that such revision will occur. But to attempt to revise $P^{*}$ is not to argue against $i t$, but rather against $P$.

This is the respect in which appearance-statements can, without any loss of relation to the world, be held inarguable. For suppose we try to investigate or dispute the sceptic's utterance of $P^{*}$ asking 'Does it really appear to you that $P$ ?'. What this question actually asks is far from clear. It might be a somewhat misleading request to reconsider $P$; but in that case we have failed to subject $P^{*}$. as such to investigation; we are really asking for a further investigation and a new, more considered judgement about $P$. Such a judgement would necessarily be distinct from $P^{*}$, and enjoy a different status. (We cannot really ask, "All things carefully considered, is $P$ still your first impression?'.) In fact, it is in the nature of investigation to accept appearances qua appearances, using them as material for inquiry into the fact of the matter. Thus the sceptic's investigations require that the contents of the arguments used to induce epoche be taken at face value within the context of that particular investigation. And the object of the investigation is never an appearance-statement as such, but the truth of its claim about the world. "What is investigated is not whether things appear so, but 
whether the underlying reality is so" (DL IX.91). The contents of appearance-statements are proper objects of investigation; the statements themselves - the 'verdicts' as such - are not.

Of course, we might 'investigate' $P^{*}$ in another way. We might question whether it does indeed report a duly passed 'verdict' - whether its utterance is sincere, made on the basis of proper procedure, and so on. Such an investigation would relate not to the content of $P^{*}$ but to the process by which the judgement assenting to it was reached and reported. Now it seems to me that there is nothing in principle to prevent the undertaking of such investigations. But to do so one will need to have a set of standards of correct procedure for deciding on and reporting appearance-statements; and such standards will be available, not to the sceptic, but only to dogmatists equipped with suitable theories of cognition. Nor will the sceptic be a promising target of such investigations. For the point of the investigation would presumably be to persuade the maker of an appearance-statement to recall it on grounds of procedural impropriety. But the sceptic's assents are, as Sextus emphasises, involuntary. Since he has neither any commitment to particular procedural standards nor any choice about his assents, the 'investigation of appearances' in this sense will not be reasonably applied to the sceptic any more than it would be by him.

\section{VII.}

Thus, by virtue of their form, the sceptic's judgemental appearance-statements are preserved in a limited respect from dispute and investigation, while nonetheless making assertions about the world. However, this juridical model is not yet adequate as an account of what the sceptic is doing. For one thing, since verdicts do incorporate claims about the world, this model may seem inadequate to underwrite the sceptic's radical opposition to dogmatism. Second, the account presented so far gives a rather voluntarist account of appearance statements: in making an appearance-statement I express a decision to take or judge things to be a certain way. But the sceptic emphasises the passive and involuntary nature of his assent to appearances (e.g. . $P H 1.13,1.19,1.22,1.193)$. This is in itself no objection to a 'voluntarist' general account of appearance-statements. On the contrary, the sceptic would hardly emphasise that his assent is involuntary if the alternative were never a possibility. But we still need to see how his claim of involuntariness is to be understood.

It seems to me that the judgemental interpretation can account for the undogmatic and involuntary character of the sceptic's appearances. But it 
will not do so through the attribution of any distinctive theoretical views to the sceptic. Rather, the everyday understanding of appearances is itself sufficient to allow for these aspects of the sceptic's appearance-statements.

In bios, it is a familiar fact that we may claim more or less authority for the judgements we make, by varying our phrasing, tone of voice, and so on. How much authority I claim for a judgement will depend on my degree of confidence in that judgement. And this will depend on the sort of information I have available, the prospective alternatives, and how probable I think it is that my judgement will be falsified. By using appearancelanguage I signal that I choose to attach relatively little authority to a judgement, on the grounds that it is preliminary and may have to be revised.

We may claim greater or lesser authority for our judgements in particular spheres. Where we consider ourselves to be particularly fallible, we may make judgements infrequently and reluctantly. But even in such areas we will sometimes find that we can't help making certain judgements. This can happen in two ways. First, some judgements are practically necessary. I may know myself to be an abysmal judge of direction, if my judgements in this area are habitually overturned by further investigation. But I may nonetheless need to decide whether to turn left or right now, forced by the grim circumstances of bios to do my best. In the other sort of case, we simply find a judgement to be inexorable or irresistible: I may just find myself convinced that I should turn left now in order to get to a certain place. This compulsion need not be mysteriously uninvestigable or nonjudgemental. It may be that in carefully and rationally thinking the matter through $I$ inexorably reach a certain conclusion; yet I remain well aware that, given my general propensities and frailties, such a conclusion is very likely to be wrong. ${ }^{37}$

In such situations there is no obvious minimum degree of authority which we must claim for our judgements. And an infinitesimally minimal claim will be not only possible but appropriate in an area in which the procedures of investigation are completely outside our competence. This will often be the case when we encounter the 'dogmatist', the bearer of special and authoritative procedures for the investigation of judgements. For example, physicists tell me that a current subject of research in the field is the precise structure of glass - ordinary window-glass. They investigate the question, 'Is glass a solid or a liquid?' Well, I know that I can't help thinking that glass

${ }^{37}$ I am here endebted to the depiction in Frede 1984 (op.cit. n.2) of the sceptic as stranded with 'views' in which he acquiesces (pp. 260-7). 
is a solid. And though this judgement seems irresistible, there's nothing irrational or uninvestigable about it. From an everyday point of view, my judgement is well supported by my various experiences of glass as hard, brittle, non-porous, and so forth. Now assume that I accept (as indeed I do) that the physicists and I are asking the same question when we ask together glass is a liquid or solid, with the difference that their concepts are more accurate. I further accept that the physicists have infinitely better procedures than I do for determining what's a solid and what's a liquid: in fact, my judgement on the subject is probably worthless. The result is that I don't really have any idea whether glass is a liquid or a solid. As far as bios goes it is a solid; but epi tôi philosophôi logôi, it could equally well be either. And so, for practical purposes, I resolve to follow the everyday appearances; but regarding the underlying reality, I suspend judgement.

It shouldn't be difficult to imagine this predicament extended to an indefinitely wide area of judgement. Nor is it difficult to imagine a world in which the 'physicists' were unable to agree in their conclusions or to support them with widely convincing proofs. In that world the localised suspension of judgement I have described could quite reasonably be transformed into a general, principled programme. One would make judgements only under compulsion. They would be preliminary and revisable to a degree asymptotically approaching infinity, and one would appropriately express their character through the emphatic use of appearance-language. And one might well feel compelled to explain this behaviour to others, and to offer them reasons to do likewise.

The appearance-statements of a person in this situation would, like ours, be expressions of judgements. They would record assents to claims about the way the world is. Nonetheless we might think that these judgements would have an unfamiliar character, and that the psychological state of such a person would be very different indeed from our own. But it would be quite hard to capture these differences in the terms of any epistemological theory. For there would be nothing special about the form, content or subject-matter of those judgements, or even in the general process by which they were reached. The differences would be in attitude and spirit alone.

In discussing the differences between Academic and Pyrrhonian sceptics, Sextus draws a distinction between two ways in which one may believe or be persuaded of (peithesthai) something. As with the two different kinds of dogmata distinguished in $P H 1.22$, the Pyrrhonian sceptic admits to one kind of condition and rejects the other. And the difference between the two forms of belief is something like the matter of spirit which I have been attempting to describe. 
"And if both the Academics and the sceptics say they believe some things, the difference between the philosophies in this regard is also very clear. For 'believe' is meant differently: in one sense, not to resist but simply to follow without any strong inclination or attachment (prospatheia), as a boy is said to believe his teacher. But in another sense it means to assent to something with a deliberate choice and as if with sympathy on the basis of a strong desire, as a dissolute person believes one who advocates the extravagant life. Since therefore those around Carneades and Cleitomachus say that they believe something with a strong inclination and that it is persuasive (pithanon), while we believe in that we simply submit without strong attachment, on this basis too we would differ from them." (PH 1.229-30)

It may seem unsatisfying to account for the differing beliefs of Academic and Pyrrhonian sceptics in terms of something so nebulous as 'strong attachment' or 'added feeling' (prospatheia). But feeling is a great deal in moral teaching, and this is an important aspect of the Pyrrhonian sceptic's programme. In common with his dogmatic contemporaries, he is the bearer of a recipe for happiness and a fighter against ethical error. We should take seriously the moralistic language in which the sceptic complains of the rashness of the dogmatists and praises the psychological state induced by scepticism (e.g., $P H 1.20,1.25-30,3.280-1$ ). If we do, then such differences of spirit may emerge as central to the sceptic's programme; and this may be all we need to make sense of the distinctiveness of the sceptic's appearances. The sceptic's appearance-statements can have as their object the same reality as the dogmatist's claims; they can be every bit as judgemental as those of his neighbours in bios. The sceptic's radicalism lies not in the form or content but in the spirit and the psychological significance of the judgements he makes. It is this which enables him to be at once a defender of bios and a subversive, both committed to the appearances and still searching for the truth.

\section{McGill University}

